\title{
The Yakutsk epos Olonkho in the context of storytelling of the Turko-Mongol peoples of Siberia: main images
}

\author{
Olga Pavlova*
}

North-Eastern Federal University named after M.K. Ammosov, 677000, 58 Belinsky str., Yakutsk (Republic of Sakha), Russian Federation

\begin{abstract}
The paper considers the main images of the epos through comparative analysis of the Yakut olonkho with the epos of the Turkic-Mongol peoples of Siberia. The author analyzed the main characters, their enemies, and female characters. The main characters, defenders of the Middle World, exhibited the features of an ideal person, exorbitant physical strength, attractive appearance, and high moral qualities. The enemies of the main character are mythological creatures and monsters. S.S. Surazakov classified the enemies of the main heroes in the epos of the Altai peoples into three groups, based on the criterion of the epos stage. He reported that a real image of an alien enemy occurs in the texts of the epos at an early feudal stage in the development of society. The enemies of the kaans-leaders of the Altai tribes are the kaans-military leaders of the conquerors. Later, the epos of the patriarchal-feudal period revealed images of feudal rulers-khans - oppressors of the common people. V. M. Zhirmunsky identified four groups of female characters: heroines, warrior-maidens, sister-assistants, and servant-slaves. According to the researchers of the Yakut epos, there are passive and active female characters.
\end{abstract}

\section{Introduction}

At present, the study of the Yakut epos focuses on the investigation of the Yakut heroic epos olonkho in the context of comparative analysis with the epos of the peoples of Eurasia and identification of their general patterns and specific features. This study presents comparative analysis of the Yakut olonkho with the epos of the Turkic-Mongol peoples of Siberia. The study aims to investigate the system of main images in the epos of the Yakuts, Altai, Khakass, Buryats, Kirghiz and other peoples. The study employs structural-typological and comparative methods.

\section{Materials and Methods}

The study of the epos of the Turkic-Mongol peoples in the historical-comparative and typological aspects were first studied by I. V. Pukhov. In the work "Heroic Epos of the Altai-Sayan Peoples and the Yakut" [1], olonkho was compared with the epos of the Altai, Shor, and Khakass peoples. Pukhov investigated the epos of the Yakuts and Shors and yielded the following conclusions: the Shor epos "Kan Kes" is similar to the Yakut olonkho. The most important similarities include: the initial loneliness of the hero who does not know his origin; the herald arriving to the hero as a bird; rudiments of the characteristics of enemies-monsters applied to the enemies-humans, although this does not apply to

\footnotetext{
*Corresponding author: olga-ksento@ mail.ru
}

them; similarity of the hero's desire to return home, immortality and cruelty of the enemy, as well as epithets; recognition of the entire course of future events, which will certainly happen. All this suggests that the Shor epos "Kan Kes" undoubtedly has common origins with the Yakut olonkho [1, 90]. Thus, the Yakut and Shor epos are of common origin.

The work by Professor V. N. Ivanov "The Yakut heroic epos olonkho in the context of comparative study" [2] poses a question about the need for comparative study of the Yakut heroic epos olonkho in the context of the development of modern epic science. Ivanov emphasizes that "expansion and deepening of comparative study of the Yakut epos will enrich theoretical study on the common Turkic epos with new facts and arguments, and introduce the new Yakut epic heritage into a wide scientific circulation in order to capture not only the specifics, but also the common feature of epic creativity. Only in this case it will be possible to consider the contribution of the Yakut people to the epic vector of world cultural development".

\section{Results and Discussion}

\subsection{Main characters}

V. M. Zhirmunsky, who characterized the main characters in the heroic epos of the Kyrgyz and Uzbeks, believed that "the folklore of the peoples of Central Asia cannot be considered separately from 
the folklore of the Turkic neighbors". The main character in the epos of the Turkic peoples of Central Asia is an ideal man of the community, a noble and brave defender of his people and territory. Hence, the traditional way of conveying the appearance of the main characters of the Turkic epos implies hyperbolic means to emphasize the heroic power superior to the capabilities of an ordinary man. Therefore, in the descriptions of the storytellers, the Kyrgyz hero Manas has a formidable appearance that inspiring fear to enemies.

"Magical invulnerability is one of the archaic merits of the epic hero in the epos of the Turkic peoples", emphasized V.M. Zhirmunsky [3, 55]. The main character of the Kyrgyz epos is endowed with magical invulnerability: he cannot be wounded with a battle ax, arrows bounce off his body, and a flying stone core cannot destroy him. Physical and magical invulnerability is characteristic of the ideal hero of the Uzbek epos - Alpamysh, who is famous for his courage and heroic power. Alpamysh, a valiant defender of his relatives and people, demonstrates not only strength, but also high moral qualities - military valor, courage and heroism. Similar to the main characters of the Kyrgyz epos "Manas", the fighting skills of the Uzbek heroes defending their native land are compared with the power of a lion, tiger, or leopard, less often with a wolf. In the understanding of the Turkic peoples, these predators embodied true strength and fighting skills.

For the Turkic-Mongolian peoples of Siberia, in particular in the Tuvan heroic epos, the main characters are traditionally fearless defenders of their people, "whose main goal is the destruction of the dark forces that interfere with the peaceful life of people" $[4,25]$. According to L. S. Grebnev, after a person gets a heroic horse and military equipment, and passes the rite of naming, he acquires the status of the epic hero. The physical and moral qualities of Tuvan heroes are manifested in hunting, obtaining a horse, overcoming obstacles, and fighting enemies. The main character of the Tuvan epos is a hero, who is honest, fearless and courageous, free from mistakes, always correct and noble. He fights mercilessly with his enemies and risks himself to save his people.

According to S.S. Surazakov [5], the main character of the epos of the Altai peoples of the period of the tribal system is distinguished by divine origin: "born of Mother Earth" or created by the forces of rudiments. Later, Surazakov differentiated the types of the main characters: a hero-hunter (mergen) and a hero-warrior (baatyr). In general, the researchers of the Altai epos (Surazakov S. S., Katashev S. M., etc.) reported that both types of heroes exhibit high ethical and moral qualities. The image of the hero in the epos of the Altai peoples is an ideal person. The storytellers described the epic hero as a giant endowed with wonderful abilities, such as immortality. He is endowed with physical and spiritual strength manifested in such moral qualities as nobility, good nature, honesty, benevolence, and justice. In addition, the hero possesses courage, stamina, endurance, fearlessness, power, male beauty, willingness to help the weak and oppressed. The life of the heroes of the epic legends of the Altai peoples is aimed at disinterested and selfless protection of the peaceful life of other people.

In the Yakut heroic epos olonkho, the main characters are the heroes of the Middle World, who defend their tribe fighting with the heroes and monsters of the Lower World. For the first time, the general features and qualities of the heroes were analyzed by P. A. Oyunsky (1927) [6]. According to Oyunsky, the Yakut heroes are distinguished by strength and height, and extreme perseverance. Olonkho heroes avoid boasting of strength and deftness, are clean, and prefer death to shame or cowardice. In addition to extremely positive qualities, heroes exhibit a number of less worthy qualities, but guarantee safety and survival in a hostile environment: the secrecy of emotions, cultivated suspicion of the actions and words of the enemy, increased vigilance and accuracy in shooting from a bow, cunning and ingenuity.

G. U. Ergis (1947) [7] characterized the main characters of the heroic epos as ideal representatives of the tribal society. Heroes are distinguished by exorbitant physical strength, attractive appearance and high moral qualities. Ergis emphasized that "the olonkho hero is a noble ancestor, a tribal leader, but not a khan or a feudal lord" $[8,202]$. In addition to ideal qualities, heroes could sometimes demonstrate arrogance, rudeness, and cruelty.

I.V. Pukhov [9] studied the main characters of olonkho and distinguished two features in the appearance of the hero of the Yakut olonkho. First, the hero is impeccable in all respects and corresponds to the ideal of the people. He has high spiritual qualities, noble goals and an attractive appearance. Second, the character of a hero changes before battles with monster enemies (abaasy). According to I. V. Pukhov, the ferocious appearance of the hero is a temporary phenomenon, which is his "combat uniform". After exploits, the hero must get rid of this "uniform" and restore his appearance corresponding to the conditions of a peaceful life. The second version of describing the main character, according to I. V. Pukhov, is a special case of the first one. Later, A. A. Kuzmina [10] highlighted the general features of the main character of the Olonkho Vilyui local tradition. The olonkho hero shows features of "otherness" that distinguish him from an ordinary person: unconventional origin (born of gods or old parents), absence of a family (full orphan or living with his sister). In all the Olonkho of Vilyui region, the main characters are not ideal, they have negative features. For example, the epic hero sometimes ignores requests, kills innocent people, quarrels with his family, takes pity on a defeated enemy, etc. Let us compare this mundane image of the epic hero with the features of the main characters of most Olonkho Tattin local tradition reported by N. A. Orosina [11], 
where the epic heroes are of divine origin and initially live in a prosperous family. Olonkho texts of the northeastern tradition are characterized by two types of the main characters. The first type is a hunter-hero, and the second is an epic hero [12].

\subsection{Enemies of the main character}

In the epos of the Turkic peoples of Central Asia (Uzbek, Kyrgyz, Kazakh, Karakalpak), the images of the enemies were considered by K. Raikhl. According to Raikhl, enemies of the heroes of the Turkic epos of Central Asia are demonic creatures hostile to man (forces of evil - from evil spirits to the devil from Christian mythology). In addition, there are Magus, Maston (old woman) and Yalmogiz (witch).

The images of the enemies of the main characters in the epos of the Turkic peoples of Siberia were studied by L. V. Grebnev, S. S. Surazakov, V. E. Mainogasheva, N. S. Chistobaeva, and others. The enemies of the main characters are mainly "mythological creatures". In the epos of the Tuvan people, the enemies of the main characters are mythological creatures - evil spirits, as well as marals and male bears, who personify the powerful forces of nature. The researcher of Tuvan folklore L. V. Grebnev reported that "the victory of the hero over the maral symbolizes the victory of man over the forces of nature" [4, 30]. In the epos of the Altai and Khakass peoples, the enemies of the main characters are mythological creatures and monsters (a six-headed serpent and a snake-dragon). In the Altai epos, the enemies of the hero are representatives of the dark forces of the Middle and Lower worlds - a seven-headed Delbegen, an old witch-woman Shimiltey and the lord of the underworld Erlik.

S. S. Surazakov differentiated the enemies of the main heroes of the epos of the Altai peoples into three groups, based on the phased development of the epos. In the epos of the period of the tribal system, the enemies of the hero-hunter are monsters who embody the hostile "forces of the elements and nature" [5, 238]. At the next stage, the hero-warrior fights with representatives of the underworld monsters and underground heroes led by Erlik, who "personify historical forces" [5, 238]. He pointed out that a real image of an alien enemy appeared at an early feudal stage in the development of society. The enemies of the kaans-leaders of the Altai tribes are the kaans-military leaders. These images of the Altai heroic epos "reflect the features of the kaans of the ancient Altai Turks" [5, 240]. Later, the epos of the patriarchal-feudal period revealed images of feudal rulers-khans - oppressors of the common people.

In the Altai epos, the enemies of the main hero are giants, who have a powerful build and strength superior to the capabilities of an ordinary warrior. In the Altai heroic epos, the development of the image of the main character led to the artistic evolution of the image of the enemy due to individualization and a more complete disclosure of a character. The mythological creatures have horns or are multiheaded monsters. For example, in the Altai epos, the cannibal Delbegen, who serves the evil khan, has seven heads, a fire-snake is six-headed. The researchers of the Altai and Khakass epos distinguished cunning, stubbornness, and stupidity as the main character features of the enemy. Moreover, folklorists showed manifestations of self-confidence and arrogance of the enemies of the main characters. The enemies of the epic heroes are their antagonists: they have no nobility and loyalty, they are prone to betrayal and treachery. In the Altai epos, the enemies of the heroes can be vicious, vile and cowardly, whereas in the Khakass heroic epos mythological creatures can be distinguished by intelligence and cunning. The enemies of the main heroes in the Turkic epos of Siberia are engaged in hostile actions against the human race, including predatory raids, destruction of settlements and cattle, pastures, capturing people, devouring living creatures, etc. In the heroic epos, they abducted brides, wives of the main characters, that is, they destroyed families and deprived the main characters of the chance to leave offspring.

It should be noted that the female characters opposed to the heroes are the dark forces. In the Altai heroic epos, an old woman Shimiltey, a sorceress or shaman from the underworld, is one of the main enemies of the epic hero. The storytellers described her as an old woman with a hideous nine-seated copper beak. Her disgusting appearance is consistent with her character: she seeks to harm the hero in various ways - from insidious intrigues and betrayal (in Altai legends the old woman Shimiltey tries to take his bride for her son) to direct destruction. In the Altai epos, the image of Shulmuska is widespread. Depending on the level of power, she either interferes with the hero on the way and creates obstacles, or opposes the hero. In the Tuvan epos, no images of female enemies can be found.

The enemies of the main characters in the Yakut olonkho were partially investigated in the works by G. U. Ergis, I. V. Pukhova, and others. The researchers of the Yakut epos named the enemies of the olonkho heroes "abaasy monsters" (G. U. Ergis, I. V. Pukhov, A. A. Kuzmina, N. A. Orosin, etc.). Abaasy monsters are inhabitants of the Lower World, whose strength is not inferior to that of the heroes.

In olonkho, heroes fight only with mythological monsters, which is the main difference between the heroic epos of the Sakha people and the epic legends of the Turkic peoples of Siberia. In Turkic texts, in addition to mythological opponents, there are real enemies of the main heroes - invading khans and the Buddhist feudal lords. This realistic expansion of the number of enemies is not characteristic of the Yakut epos, which continues to reproduce the situation of a more archaic society. Hence, the images of khans and feudal lords are absent in olonkho texts. In olonkho, the images of the heroes of the Lower World show their inhuman origin - they are one-armed, one- 
legged and one-eyed. In addition to this appearance, the texts of the Yakut olonkho emphasize the description of the eyes of the enemies. Their eyes contradict all the aesthetic canons of the Sakha people: strabismus and myopia are inherent in the inhabitants of the Lower World, the color of the eyes can be white or, conversely, differ. "The discrepancy between eye and skin color seemed especially ugly to brown-eyed and yellow-faced Yakuts", according to I. V. Pukhov [9, 138].

In olonkho texts, Abaasy women of the Lower World of different ages come into conflict with the main characters. Moreover, in some texts of the Yakut heroic epos, it is the heroes or udagan women (shamans) of the Lower World who are serious enemies of the heroes. In olonkho texts of the Vilyui regional tradition, women of the Lower World kidnap girls for their relatives. Tungus epic hero (Ard'amaan-Dyardyamaan is another serious enemy of the heroes.

Thus, the enemies in the Turkic heroic epos personify dark forces, which was manifested both in actions and in appearance. Thus, the enemies in the Turkic epos of the peoples of Siberia exhibit an extraordinary strength and ugliness: body defects, the presence of horns, many heads. Abaasy monsters from the Yakut olonkho differ from their counterparts from the Turkic epos in having only one limb (arm, leg) and extremely light, white eyes. In the Yakut epos, the heroes of the Lower World are characterized by stupidity, naivety, and credulity, due to which the main characters defeat their opponents. In contrast to heroism, I.V. Pukhov noted such negative features of the heroes of the Lower World as promiscuity in food, uncleanliness, rudeness, bragging, persistence, cruelty, frivolity, lust and even a tendency to cannibalism (according to I. V. Pukhov, the heroes of the Lower World eat each other). In the Yakut olonkho, the heroes of the Lower World seek to marry the girls from the Middle World and often use the gift of werewolf to take the girls.

\subsection{Female images}

In the Uzbek heroic epos, V.M. Zhirmunsky identified four groups of female images: heroines, warrior maidens, sister-assistants and servant-slaves. The image of the epic heroine, according to V.M. Zhirmunsky, "embodies the female ideal created by the people". A beauty with the strength of a warlike Amazon helps the wounded hero, engages in battle with enemies, and saves her beloved from death. Another image is a warrior maiden, which is significantly different in her independence and readiness to fight, not only to protect her beloved. The sister of the hero in the texts of the Uzbek epos helps her brother, admonishes him before the battle, and patiently waits for his return. The servant-slave brings the features of adventurism and fun.

Let us consider the images of women in the epos of the Turkic peoples of Siberia. In Tuvan heroic legends, a woman is completely subordinate to a man, being the object of matchmaking or capture. In a number of legends, the wives of the heroes help their husbands to defeat the enemy, that is, they perform the function of assistants to the main characters. Unlike other heroic epics of the peoples of Siberia, the Tuvan epic contains the image of a traitorous wife as a negative character.

In the Altai heroic epos, female characters are classified into four groups: the daughters of the kaans, the sisters of the main characters, the werewolf maidens, and the wonderful maidens. All female characters are characterized by wisdom and patience, and willingness to recognize male superiority in the family. The daughters of the kaans are beauties for whose sake heroic deeds are performed, conflicts begin, and rivalry arises. Werewolves have the gift of reincarnation into a swan, goose, frog, puppy and sparrow. Wonderful maidens - daughters of Heaven, Moon, Sun - are endowed with magical powers and beauty.

In the Yakut epos, female characters were studied in the works by P. A. Oyunsky, G. U. Ergis, I. V. Pukhova, N. V. Emelyanova, A. A. Kuzmina, A. N. Danilova, N. A. Orosina, and others. Images of udagan women (shaman women) in olonkho texts were the subject of scientific research by A. Ye. Zakharova, S.D. Mukhopleva, and L. S. Efimova. A number of aspects of this issue were studied by the philosophers K. D. Utkin and A.S. Popova, ethnographer N. A. Alekseev, musicologist A. P. Reshetnikova, and others.

P. A. Oyunsky in his work "The Yakut tale (olonkho), its plot and content" attempted to clarify female characters. He proposed the classification of female characters into passive and active ones. The heroines of the Yakut olonkho living in the midst of tribal wars are the cause of the fight between the main characters and their enemies, they follow the victorious hero as wives or brides, but at critical moments women from the Aiyy Aimaga tribe (inhabitants of the Middle World) demonstrate activity, initiative, and resilience. The heroines of the Yakut olonkho, despite their external fragility and tenderness, are able to deceive the monsters, help the main character and ensure the outcome of the struggle in favor of the hero. P. A. Oyunsky isolated the images of udagan women (shamans) who play a special role in the life of the archaic community: "Traces of matriarchy are found in the cult, which in the heroic era (olonkho) is in the hands of a woman in all three worlds ... In all three great associations that divided the universe, there are udagan women" [6].

G. U. Ergis showed two types of female characters. The first type includes the image of the betrothed bride of the olonkho hero. A girl from the Aiyy Aimaga tribe (inhabitants of the Middle World) is endowed with excellent physical and moral qualities, beauty, intelligence, practical skills and abilities. She is an ideal wife and mother, who is waiting for her hero. The second type includes 
shamans - servants of the Upper or Lower Worlds, who are omnipotent, courageous and decisive. Shamans have the gift of reincarnation into beautiful snow-white Siberian cranes or huge spotted bulls, their magic allows them to resurrect fallen heroes, predict the future, and win battles.

I. V. Pukhov divided female characters into two types and differentiated them according to the principle of social activity: passive and active. To passive heroines, he refers beauties who do not play an important role in the development of the olonkho plot. Active heroines include girls who are partially or fully involved in the events described in olonkho, and they are even able to control them. Representatives of active heroines are most often the wives or sisters of the heroes. They help the heroes, give advice, and warn against impending disasters.

In addition to the main female characters, I. V. Pukhov introduced the image of an old woman Simekhsin - a traditional episodic image of the Yakut olonkho. In many olonkho texts, Simekhsin appears as a "comic character", who is punished for inadequate actions. In other texts, the old cowshed woman is a devoted servant who, with the help of her prophetic dreams, warns the owners of the impending danger. Pukhov insisted that the image of Simekhsin is "a deeply ancient image created when the Yakuts lived in the neighborhood with the rest of the TurkicMongol peoples and had a close connection with them" [9, 203].

N. V. Emelyanov isolated shaman women and clairvoyants (udagan women) into a separate group. According to $\mathrm{V}$. V. Illarionov, the presence of udagan women (shamans) in olonkho is a manifestation of an archaic, relict motive. In the Yakut language, the shaman is called udagan. This word is derived from $u t$ or $o t$, which means fire, and gan is a feminine suffix. Hence, the priestess of fire is meant. K. D. Utkin cites the following information from the archives by E. N. Ivanov: "Totemsancestors are associated with the cult of the Udagan: a bear, a wolf, a crow, a hare, a dog, a cow, who are assistants and companions of the Udagan. Omnipotent shaman women reincarnate at the right time into Siberian cranes or black ravens ... Udagan women typically reincarnate into a bear or a wolf" $[13,107]$.

A. A. Kuzmina in the Yakut olonkho texts of the Vilyui regional tradition classified the female characters into three groups: women of the Middle World, heroines, shamans. A. N. Danilova studied in detail the images of female heroines in the Yakut olonkho. This image was divided into three groups: hearth keepers, heroines, and sorceresses.

N. A. Orosina studied the images of the Udagan women (shamans) in the texts of the OlonkhoTattinsky local tradition and divided them into two groups: udagan women of the Aiyy (Middle World) tribe and the Abaasy (Lower World). The images of udagan women of the Middle World are represented by two subgroups - udagan assistants and heroines.
In olonkho texts of the northeastern tradition (O. K. Pavlova), there are three groups of female characters. The first group is represented by udagan women (shamans) from three worlds, divided according to their functional characteristics into three subgroups. Udagan women of the first subgroup are healers, inhabitants of the Upper World, who help the main characters as white Siberian cranes. Udagan women of the second subgroup inhabiting the Middle World are assistants and advisers of the heroes. In many cases, they are wives and faithful companions of the main characters. Udagan women of the Lower World oppose the heroes and fight them. The second group of female characters includes images of the girls of the Middle World. Passive heroines are dependent and defenseless. The second subgroup includes girls who are involved in the development of the olonkho plot. Active heroines are distinguished by intelligence and quick wit, possess the power of magic and reincarnation. They are assistants to the heroes. The third group includes images of old women Simekhsin. In the olonkho of the northeastern tradition, this image is different than that in other traditions. The image of Simekhsin, in our opinion, is collective. Old cowshed women have the gift of reincarnation and divination, they are quick-witted, assistants and saviors.

\section{Conclusion}

As a result of the study, the main images were identified, such as the main characters, enemies and female characters. The main characters are the defenders of the Middle World, reveal the features of an ideal person, and possess exorbitant physical strength, attractive appearance and high moral qualities. The Altai and Yakustk epos is characterized by the images of the hunter-heroes. The enemies of the main characters are mythological monsters. The epos of the patriarchal-feudal period revealed images of feudal rulers-khans. It should be noted that the epos of the Turkic-Mongolian peoples features the phased development. The Yakut epos belongs to archaic epos, followed by the early feudal stage in the development of society and the patriarchal-feudal period. Female characters were divided into several groups: heroines, warrior maidens, sisters, wives and slaves. P. A. Oyunsky and I. V. Pukhov classified female characters in the Yakut olonkho according to their functional purpose - passive and active characters, although some brides of heroes are heroines or shamans. Most researchers considered female characters as brides and wives of the main characters, to whom they return after battles. Unlike the epos of the Turkic peoples of Asia and Siberia (Tuvans, Altai), where a sister is the main adviser, housekeeper and friend, the Yakut olonkho does not emphasize the image of a sister. It should be noted that the epos of the related peoples arose at the junction of historical and spiritual contacts. In the future, comparative study of the plot-compositional 
structure of the epos in the Turkic-Mongolian epos of the peoples of Siberia and in the Yakut olonkho seems to be promising.

\section{References}

1. I. V. Pukhov, The heroic epos of the Altai-Sayan peoples and the Yakut olonkho (SB RAS Publishing House, Yakutsk, 2004)

2. V. N. Ivanov, Yakut heroic epos Olonkho in the context of comparative study, Bulletin of the North-Eastern Federal University named after M. K. Ammosov: Epic series 1(1), 22-29 (2016)

3. V. M. Zhirmunsky, Uzbek folk heroic epos (Goslitizdat, Moscow, 1947)

4. L. V. Grebnev, Tuvinian heroic epos (Vostochnaya literaturaMoscow, 1960)

5. S. S. Surazakov, Altai heroic epos (Nauka, Moscow, 1985)

6. P. A. Oyunsky, Yakut tale (olonkho): its plot and content (reprint) (North-Eastern Federal University named after M.K. Ammosov, Yakutsk, 2013)

7. K. G. Orosina, Nyurgun Bootur the Swift. Yakutsk olonkho (Yakutsk Publishing House, Yakutsk, 1947)

8. G. U. Ergis, Essays on Yakut folklore (Bichik, Yakutsk, 2008)

9. I. V. Pukhov, Yakut heroic epic olonkho. Basic images (Publishing House of the Academy of Sciences of the USSR, Moscow, 1962)

10. A. A. Kuzmina, Olonkho Vilyui region: existence, plot-compositional structure, images (Novosibirsk, Nauka, 2014)

11. N. A. Orosina, Tattinsky local tradition of the Yakut epos olonkho: forms of existence, main images and motives, $\mathrm{PhD}$ dissertation (FSBSI Institute of Language, Literature and Art named after G. Tsadasy of the Dagestan Scientific Center of the Russian Academy of Sciences, Yakutsk, 2015)

12. O. K. Pavlova, Northeastern tradition in the Yakut olonkho: images, plots, poetics, $\mathrm{PhD}$ dissertation, (Adyghe State University, Maykop, 2018)

13.K. D. Utkin, Religious and philosophical worldviews of the indigenous peoples of Yakutia (Bichik, Yakutsk, 2000) 